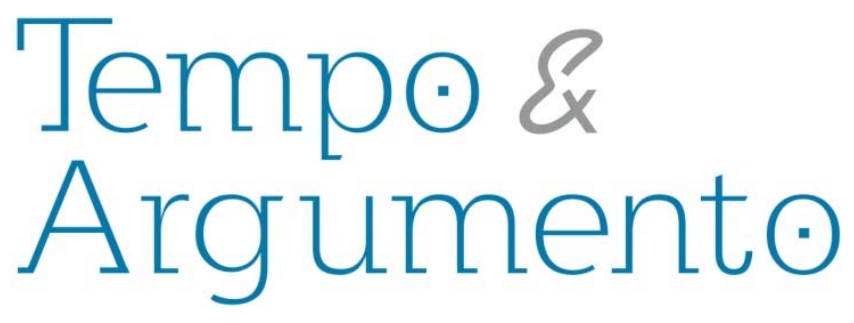

\title{
Antifascist Front and military politics of the Communist Party of Chile under dictatorship, 1973-1980
}

\begin{abstract}
This article inquires about the route of the military politics of the Communist Party of Chile, particularly under its political commitment to the Antifascist Front (1973-1980). In this regard, we argue that, in a first stage, this party pursued its military politics primarily based on evaluations about the causes of Allende's defeat. This implied an almost unrestricted continuity of its military politics during the early years of dictatorship. However, after the first measures taken in order to palliate its shortcomings, and also face the imminent extension and institutionalization of dictatorship, there was a slow, but significant expansion of its military politics in the late 1970s, a dynamics that ended up contributing both to the political reconfiguration of its militancy and its commitment to bring the dictatorship to an end.
\end{abstract}

Keywords: Dictatorship; Communism; Military Policy; Political Violence; Chile

\author{
Claudio Pérez Silva \\ Ph.D. Professor at the School of History, \\ Universidad Academia de Humanismo Cristiano, \\ and at the Department of History, \\ University of Santiago, \\ Chile. \\ claupere73@yahoo.com
}

\section{Translator}

\section{Evandro Lisboa Freire}

Translator and copy editor in English and Spanish. MA in Applied Linguistics (PUC-SP).

Specialist in Translation (UNIBERO). Brazil

elf_translation@yahoo.com.br

\section{To cite this translation:}

PÉREZ SILVA, Claudio. Antifascist Front and military politics of the Communist Party of Chile under dictatorship, 1973-1980. Tempo e Argumento, Florianópolis, v. 7, n.16, p. 444 - 472. set./dez. 2015. Original title: El Frente Antifascista y la Política Militar del Partido Comunista de Chile bajo dictadura, 1973-1980.

DOI: $10.5965 / 2175180307162015444$

http://dx.doi.org/10.5965/2175180307165201544

\footnotetext{
${ }^{1}$ This paper is a part of the research project FONDECYT no. 1130323, Historical context and political dynamics of the armed insurgency in Chile (1978-1994)
} 


\section{A Frente Antifascista e a Política Militar do Partido Comunista do Chile durante a ditadura, 1973-1980}

\begin{abstract}
Resumo
Este artigo investiga a trajetória da política militar do Partido Comunista do Chile, particularmente durante sua aposta política de Frente Antifascista (1973-1980). Nesse sentido, sustentamos que, em uma primeira etapa, esse partido desenvolveu sua política militar fundamentalmente com base nas avaliações realizadas acerca das causas da derrota de Allende. Isso implicou uma continuidade quase irrestrita de sua política militar durante os primeiros anos da ditadura. Contudo, a partir das primeiras medidas adotadas para atenuar suas deficiências, assim como, também, diante do iminente prolongamento e institucionalização da ditadura, produziu-se uma lenta, mas significativa ampliação de sua política militar no final da década de 1970, dinâmica que acabou contribuindo tanto para a reconfiguração política de sua militância como com sua aposta para acabar com a ditadura.
\end{abstract}

Palavras-chave: Ditadura, Comunismo, Política Militar, Violência Política, Chile.

\section{El Frente Antifascista y la Política Militar del Partido Comunista de Chile bajo dictadura, 1973-1980}

\begin{abstract}
Resumen
Este artículo indaga la trayectoria de la política militar del Partido Comunista de Chile, particularmente bajo su apuesta política de Frente Antifascista (19731980). Al respecto, sostenemos que, en una primera etapa, este partido desarrolló su política militar fundamentalmente en base a las evaluaciones realizadas sobre las causas de la derrota de Allende. Lo anterior implicó una continuidad casi irrestricta de su política militar durante los primeros años de dictadura. No obstante, a partir de las primeras medidas tomadas en función de palear las deficiencias de ésta, así como también frente el inminente alargue e institucionalización de la dictadura, se produjo una lenta pero significativa ampliación de su política militar a fines de los 1970, dinámica que terminó contribuyendo tanto a la reconfiguración política de su militancia como a su apuesta para terminar con la dictadura.
\end{abstract}

Palabras clave: Dictadura; Comunismo; Política Militar; Violencia Política, Chile.

\section{Scenarios and political dynamics of the Chilean dictatorship, 1973-1980}

The Coup d'État of September 1973 was a complete military intervention, designed and embodied by the set of Armed Forces and Police in order to reconfigure the Chilean society through new social, political, and economic conceptions. Therefore, it was a refoundation (GOICOVIC, 2006; GÁRATE, 2012). Due to this objective, the dictatorship established itself on a political, ideological, social, and military basis through a broad alliance of forces - mainly anticommunist - and under a totalitarian and comprehensive 
repressive political rationale or conception framed by the canons of the National Security Doctrine and the counterinsurgency strategy.

Within these political frameworks, the most comprehensive and forceful repressive offensive against the major political figures of the Chilean left-wing was carried out, as well as the various expressions of Chilean popular movement. To do this, a particular kind of repression was systematically implemented that escaped the traditional repressive mechanisms and forms with which the State, the ruling classes, and the security forces, at different stages of Chile's history, had faced the leading role and the various political and social onslaughts of the popular movement and the Chilean left-wing in the national political dynamics.

In this context, the arrest and disappearance of individuals emerged, as well as the execution of prisoners, as well as mass exile of thousands of Chileans, political imprisonment, and systematic torture of prisoners, most of them militants of leftist parties with a heavy weight in the organized working class, the peasant trade union movement, the movement of settlers and students, thus ensuring the isolation of political organizations and their ability to adjust under the roof of the popular movement dynamics (GOICOVIC, 2006; ÁLVAREZ, 2003; PINTO, 2006). Terror, expressed as State terrorism, was then the preferred and standardized way to stop any attempt of social political rearticulation or resistance to dictatorship (MOULIAN, 1997).

Once these objectives are met, the political, social, and military conditions for the capitalist reestablishment and the construction of a new society were guaranteed. With this, the dictatorship carried out the refoundation of the Chilean society and economy around the neoliberal matrix. The new economy strengthened the nature of dependence and export of raw materials, encouraging foreign investment (other than copper) in the forest, fishing, and agricultural industries. State companies were privatized and import of manufactures was favored, suffocating and exterminating much of the national industry (GÁRATE, 2012; TIRONI, 1988; CAMPERO, 1984).

It is within this historical framework of bloody repression of the Chilean left-wing and the popular movement as a whole, as well as a profound restructuring of the Chilean 
society, where we must inscribe the discussions and the route of the political outlines developed by the Chilean communism to face the dictatorship.

\section{The Communist Party of Chile and the Politics of the Antifascist Front}

The first responses and political lines raised by the Communist Party of Chile (PCCh) after the Coup d'État were primarily aimed at the time after the revival of communist militancy, in order to preserve the various regional and national structures, as well as to ensure party unity and its respective political leadership with regard to the bulk of militancy. From the political viewpoint, both in the countryside and exile, the primary commitment of the Chilean Communists was focused around allegation of violations of human rights by the dictatorship, the work of solidarity with prisoners, as well as depicting the Chilean usurpers as a Board of fascist nature, highlighting through this the alleged national and international political isolation where it was. On the other hand, from the viewpoint of its actions and considering the traditional centrality assigned by the PCCh to the working class, the outlines and efforts of the PCCh were also driven to keep the ties and various organizational expressions of the Chilean popular movement where the communists had a great influence, particularly those from the trade union context.

The urgency of the reality imposed by the dictatorship has marked the rhythms and set the direction of tasks and objectives immediately unfolded. This time of the fight against the fascist board framed all party efforts around the search for political ways and proposals to develop, particularly in the segment of the communist militancy that was under clandestine conditions and harassed by repression in Chile. This element of context is of utmost importance when analyzing the features and contours of the politics pursued by the PCCh immediately after the Coup d'État. The setting and the needs imposed by the dictatorship implied, among other things for the communist leadership in Chile, conservation to a large extent and without further questions, political conceptions and historical views built in relation to the Chilean society.

In the same vein, it meant the persistence of programmatic and strategic elements, as well as the strengthening of a rationale involving analysis and considerations of forces 
the Coup d'État itself. In political terms, it meant that the new interpretations developed by the PCCh in the framework of the fight against the dictatorship might tend to reinforce its proposal for a Chilean route to socialism or add some elements of analysis - such as the fascist nature of the Board and the weight of fascism in a part of the Chilean officialdom rather than discussing the political route of this party. The elements of tradition and continuity had to change. What was new in the political analysis and commitment, in this case the Antifascist Front, did not imply a change of direction considering the setback caused by the defeat of the UP, but rather strengthening the rhythms and direction of the project.

The previous party dynamics may be identified through the review and study of the first statements and political definitions reached by the PCCh about the dictatorship and the way how to deal with it. Similarly, through the allusions and political analyses in which the defeat of the Unidad Popular was addressed. An element of continuity is the permanent appeal to the leftist unity and the expansion needed due to the political alliances to defeat the Military Board, particularly to the inclusion and joint work with the Partido Demócrata Cristiano. In this political struggle framework, the PCCh proposes, there was a place for "every man, woman, or young individual from our people," no matter whether they had been within the opposition to Unidad Popular or confused "by the propaganda of reactionaries." What was important for the communists consisted in the fact that millions of Chileans had "seen fascism face to face and they were willing to fight against it"2.

Through these political formulations, we may identify two major elements that remained present in the discourse and the commitments of the PCCh during the dictatorship. On the one hand, "the call to a wider unity (typically from 'Frente Popular') and, on the other, emphasis on the unity at the base, beyond the Christian Democratic

\footnotetext{
${ }^{2}$ La voz de orden es la unidad, Santiago, 11 de Octubre de 1973, In: Desde Chile hablan los comunistas!, 32.
} 
Directive refused a formal agreement with the PCCh..." (ÁLVAREZ, 2003). And the other significant element to emphasize in these first statements is related to the problem of the struggle forms and the role played by the masses in it. The main thing, in our view, is the centrality the PCCh assigns to the mass struggle in this context, providing with it a clear detachment from positions early adopted by Movimiento de Izquierda Revolucionaria (MIR) to face the dictatorship, particularly around armed forms of struggle. Against the latter, they pointed out the importance of attributing "the emphasis to organization, unity, and mass struggle and to the increasing development of its political consciousness"3.

They also propose that, by mobilizing popular masses, it is possible to bring repression, crime, and dictatorship itself to an end. In conclusion, that "mass struggle will achieve the final victory of people through conscious creative work, classrooms open to a fruitful dialogue, and rebellion of young individuals, peace and tranquility in the households"4. Under this conception, the Chilean left-wing should endlessly search for unity with the broader social and political sectors, including the middle classes, the bourgeoisie, and the antifascist sectors of the Armed Forces, which together had to carry out the democratic reconstruction.

Thus, through the first reflections developed by the communist leadership regarding the experience of Unidad Popular (UP), a major political bridge with the objectives set depending on the end of the dictatorship was established, providing a meaning, foundation, and continuity to two major thematic axes: struggle forms and alliance-based politics. Regarding the balances related to Allende's defeat, the PCCh highlights among the main factors causing its collapse the isolation of "the working class." The previous situation, according to the PCCh, had caused a significant and negative change in the correlation of forces favorable to social transformations, a context skillfully used by the usurping sectors to trigger their strategy to overthrow Unidad Popular. Within this framework, the PCCh stated that both the nature of the Coup d'État and that of the dictatorship itself (fascist), with their repressive and antidemocratic rationale and dynamics, as well as the negative impact of the policies carried out by "the Board" on most

\footnotetext{
3 Ibid. 27.
}

4 Ibid., 32. 
of the population, generated the conditions favorable for a broad political and social unity against the Military Board.

Under this conception, the "fundamental enemies of the people of Chile" remained as the sectors and groups that had materialized the Coup d'État and also benefited from the dynamics and objectives imposed by the dictatorship. According to the communists, these sectors were "the same from the past: imperialism and monopolist and landowning oligarchy"5. This initial definition is illustrative of what we are proposing, as it reinforced the general conceptions concerning the nature of the Chilean revolution and the fundamental enemies who had established this party before the Coup d'État and since its occurrence, it is a continuation of a large part of the rationale and ways how the communists conceived the development of their politics.

Based on the above, they suggested there had been created

(...) on an objective way, conditions for a very broad united front. Politically, this situation reaffirms the validity of Unidad Popular as a unitary expression of the people, but at the same time, there is a need to go beyond, to the joint action and unity with sectors of the people that were not with Gobierno Popular'.

What was significant about these reflections is that they set criteria and content under which the alliance-based politics of the PCCh during the 1970 s should be interconnected. Through it, we can understand, on the one hand, the permanent and key quest to develop joint work with Democracia Cristiana. On the other hand, detachment from and rejection of the so-called ultra-left wing. According to the PCCh, the main role in the struggle against the dictatorship was played by the masses, expressed by the mobilization capacity and breadth with all democratic, progressive, and antifascist sectors. According to the PCCh, every political activity alien to or detached from the masses, their traditions and skills, were not only a mistake, but they also called and justified the activities and repressive politics of fascism on the broad field of the antifascist democratic sectors.

\footnotetext{
${ }^{5}$ Ibid., 44 .
}

${ }^{6}$ Ibid., 45 . 
Hence, the rejection to any political activity suggesting armed fight against the dictatorship was openly proposed.

In face of such initiatives, they pointed out that the masses and the popular movement should expel from their practices and conceptions those "petit bourgeois" ideas and commitments of support or "external impulses" so that the people can go on and develop their struggles. Thus, they proposed that "the true mass movement, capable of generating a revolutionary situation is constituted through the concrete problems faced by the people"7. Therefore, the PCCh criticized and rejected any attempt to develop armed actions and those isolated from the masses, calling them primarily to take activities aimed at the occupation, maintenance, and recovery of spaces and democratic political dynamics and through this force, it was possible to isolate the dictatorship on a political basis and nullify or stop the reactionary violence (repression) by the Military Board. Through these considerations, efforts were directed to build a broad political alliance with Democracia Cristiana, rejecting any attempt of political articulation with MIR.

Since 1974, the PCCh was decisively devoted to the creation of the Antifascist Front, pointing out the need to use the alleged cracks observed within the Armed Forces due to tensions between some generals and Pinochet. Similarly, it assigned great political significance and impact among the Christian democratic militancy, the emergence of criticism inside it and detachment from important Christian democratic leaders who participated in the usurping framework concerning the fascist military men (ÁLVAREZ, 2003; ROJAS, 2011; BRAVO 2010). Thus, by reading about the wide range of rejection and the national and international political isolation which the Military Board was facing, the PCCh showed its proposal to create the Antifascist Front, whose purpose was

(...) the defeat of the dictatorship, the destruction of the totalitarian and police-based State (...), the construction of a new democratic, national, pluralistic, and popular State that develop all achievements our country and its people have reached, which overcomes the power of imperialism and the monopolist and agrarian grande bourgeoisie and safeguard the interests of big national majorities, building a new economy that guarantees an independent development of the country ${ }^{8}$.

\footnotetext{
7 Boletín del Exterior. Partido Comunista de Chile, $\mathrm{n}^{\circ}$ 1, enero de 1974, 9.

${ }^{8}$ Boletín del Exterior. Partido Comunista de Chile. $n^{\circ}$ 4, mayo-junio 1974, 8.
} 
It was also added that the struggle of Antifascist Front, due to its features and extent, might generate the most democratic government that Chile has had and that the struggle for a new democracy was the only route that could lead "to the proletariat and its allies to form a superior society more just, the socialist society, based on a process that is supported by the vast majority of the country" 9 .

Based on the above, we may argue that during the 1970s, regardless of what the communists added or specified, some themes concerning the defeat of Unidad Popular (in which they even assumed a significant level of responsibility), generally these new reflections did not imply substantial changes in the Antifascist Front politics and the key role assigned to Democracia Cristiana in the political process of unity to face the dictatorship. The crucial point to the PCCh was avoiding the isolation of the working class and getting closer to the middle class, as well as the democratic and antifascist sectors of the Armed Forces and the political core, mainly the PDC, towards the social transformation project carried out by the left-wing. In the same vein, they ratified tactical differences from MIR and the criticism of acting isolated from the masses, as well as based on adventurism and terrorism. The masses kept their force at least until the Plenary session in August 1977 and, to a lesser extent and intensity, until the end of the Antifascist Front politics in 1980.

Regarding the route and features of the Antifascist Front, the bulk of researchers studying the Chilean communism during the dictatorship, they argue it ratified and went on with its historic commitment of gradual and institutional nature regarding the process of socialist construction (based on Frente Popular), as well as with the core elements of its (large) alliance-based politics having social transformations in mind and in collaboration with the so-called national bourgeoisie (MOULIAN Y TORRES, 2010; VARAS, 2010; RIQUELME, 2009; BRAVO 2010; BASCUÑÁN, 1990; ÁLVAREZ, 2011; ROJAS, 2010; VENEGAS, 2009). In this line of analysis, Hernán Venegas $(2008,279)$ argues that even in the worst moments experienced by the PCCh during the dictatorship, the product of the systematic repression that it underwent due to the repressive agencies, it "turned its gaze to what

9 Ibid., 8. 
As pointed out in the beginning, we are interested in identifying and understanding the readings and ideas that supported the politics of the PCCh in the early years of the dictatorship and its relationship with the route and development of its military politics. In this regard, we believe it is not possible to grasp this process without thinking about the particular historical context in which the political reflection and militant life unfolds, marked among other things by the tripartite political status of defeat-clandestinityrepression, mass exile of the militancy, and its boards of direction, and finally, tension and need both to solve the binomial search and identification of the causes of the defeat of Unidad Popular and the formulation and materialization of a correct politics to bring the dictatorship to an end as soon as possible. These contextual elements, from our viewpoint, those establishing the tone of the politicization and repoliticization process of the communist militancy during the 1970 s.

Regarding the political dynamics described above, Rolando Álvarez (2011) points out that the experience of the PCCh in the period 1973-1980 consists in continuity and change in time. On the one hand, there is persistence in the work and centrality of the "mass struggle" and a clear continuity of its alliance-based and moderate vocation; on the other hand, change through the experience derived from defeat (imprisonment, torture, betrayal, and death of its members) and fear on a daily basis to bring the dictatorship to an end. In another sense, it is pointed out that this process allowed the reconfiguration of the communist political culture and, therefore, the line of the Antifascist Front is inscribed and included in the same process of continuity and change. Continuity, by regarding it as partial achievements of the commitment, some goals met in the context of mass struggle and dialogue with Democracia Cristiana, aspects that according to the author might end up reinforcing the alliance-based rationale and tradition. Change, in relation to the sense of failure due to being unable to put the political unity into practice with Democracia Cristiana, something which generated in the communist militancy the need to rethink and find, in the context of institutionalization and extension of the dictatorship, new struggle forms. And, by sharing this, we just intend to identify and characterize this process of continuity and 
change through the development of the military politics of the PCCh during the commitment of the Antifascist Front.

\section{The military politics of the PCCh during the Antifascist Front politics}

Regarding the military politics of the PCCh, we think there is a need to point out at least three considerations. First, it must be characterized and analyzed in the light and in a direct relation to its politics as a whole, in this case the Antifascist Front politics. Second, the military politics is also subject or marked by the dynamics of continuity and change, especially considering the context in which the politics is formulated and materialized (defeat-repression-clandestinity), militant scenarios and experiences in the various party politics structures and spaces (e.g. militancy in exile and spaces for reflection and debate that fueled such a formulation and development, Cuba and the German Democratic Republic, among others). Third, the military politics of the PCCh during this period is closely related to the political balances unfolded by this party concerning the pathway of the Chilean route to socialism and particularly with regard to Allende's defeat.

In fact, we think that these reflections and balances became a major general source of military politics of the PCCh within the period 1973-1977. Similarly, they provide us with significant elements that allow us to grasp the meanings and nature of the commitments developed by this Party in relation to the military problem during this process. Similarly, we think it can tackle the military politics of the PCCh within this particular period, through two aspects. One of them, its view (balance) concerning the Armed Forces and their role in the Coup d'État; the other is related to the problem of the struggle forms. Overall, it is critical to grasp most political decisions made by this party in relation to the military problem, as well as regarding its politics towards the Armed Forces in the context of the struggle against the dictatorship.

Regarding the view of the PCCh in relation to the Chilean Armed Forces, it has set on an early basis (a few months after the Board was established) the concerns and parameters through which its politics should be situated in face of them. For instance, it defined that the Chilean people had 
(...) the right to also consider as an objective the creation of a new type of armed and police forces, or at least eliminate the military institutes, police officers and investigations, the fascist elements in order to assure Chile that what happened will never occur again ${ }^{10}$.

Through the analysis of the vast majority of the documents and statements of the PCCh which addresses the theme of the Armed Forces, it is possible to point out that the bulk of their political formulations tended to identify and separate the usurping sectors on the one hand and the institution (Armed Forces) on the other. This implied characterizing and grasping the usurping sectors of the Armed Forces as factions or even as betraying sectors or alien to them, when established, for instance, that such fascist sectors led the Chilean Armed Forces to break with their democratic traditions, mainly due to attachment to the National Security Doctrine and the goals and interests of imperialism.

The idea of pulling the set of military institutions by the usurping sectors gives rise to the conception of split Armed Forces, fragmented, in dispute, and disembodied. In this light, the usurping sectors instead of the set of Armed Forces were those carrying out the Coup d'État and the bloody repression to the popular and leftist movement: "the generals and officers who accepted the external and internal pressures to pull their institutions to participate in the conspiracy against Chile and its people" had trampled "the prestige and responsiveness of the Armed Forces in face of the people and the world and end up destroying them by persevering in this direction”"1.

What is interesting about these readings is the fact they serve as a basis for the formulation and justification of their politics in face of the Armed Forces, so for its military politics, claiming, for instance, that as a Party, both under Allende's government and during the dictatorship, they have never conceived "social struggle as a fight between civil and military individuals," since there were sectors within the Armed Forces wearing "the uniform thinking about their duties in relation to the country and they have been taken to participate in terror unleashed against the people despite their democratic feelings." Therefore, it was established that one of the main efforts of the popular movement should

\footnotetext{
${ }^{10}$ La voz de orden es la unidad, op. cit., 28.

${ }^{11}$ Unir millones para poner término a la pesadilla. (Declaración formulada en Santiago el 20 de diciembre de 1973), In: Desde Chile..., op. cit., 43.
} 
oligarchy"12. In the same vein, it was stated that the Armed Forces still had within them an "honorable, honest, patriotic" alternative contrary to that of "the protection to the economic privilege and executioner of the people." According to the PCCh, this line had been demonstrated by General Schneider and General Prats, and by "many others, who were killed after refusing to recant betrayal due to violation of their duties," and that the movement of constitutionalist sectors within the Armed Forces and installation of betrayal among their members involved breaking with the democratic traditions and abandoning professionalism at the expense of serving the interests of a minority. On such a basis, it was established that the Chilean armed forces should "come back to observing the traditions of constitutionalism and professionalism that honored and distinguished them in the world, while practiced, and people should never have detached from this"'13.

As we have seen so far, the creation of new Armed Forces and the elimination of fascist elements observed within the military corps were installed as the main concern and they also became important military and political objectives in relation to the general commitment of the PCCh in this period and especially during an alleged scenario of end of the dictatorship and beginning of the democratic recovery process. Through these conceptions, we may argue that the fundamental political commitment thereafter, the most specific and strategic political goal at the time was avoiding again, in a hypothetical scenario, the re-emergence of the process of political and military grouping carried out by reactionary and fascist sectors within the Armed Forces based on rejection to the process of democratization of the Chilean society towards a socialist transformation. In short, avoiding the emergence of usurping and fascist tendencies, by arguing that "what Chile requires and demands are Armed Forces that never again, under any circumstances, are against the interests of the people and become, as institutions, gatekeepers of interests of the oligarchy and imperialism"14. These commitments, set on a very early basis by the

\footnotetext{
12 Ibid., 44.

13 lbid., 131-132.

${ }^{14}$ Los acontecimientos en Chile: visión de los comunistas. (enviado desde Santiago, en junio de 1974, a Revista
} 
leadership of the PCCh, will become the structuring pillars and organizing elements of its politics towards the Armed Forces, at least until the late 1970 s.

In the same line of analysis, it is proposed that a key problem to be solved by the Antifascist Front in the tasks of democratic reconstruction is "ensuring a profound transformation in the Armed Forces and Carabinieri," and this leads to the conclusion that "the establishment and permanence of the democratic State to which we aspire would not be guaranteed without solving this problem." According to its view, the articulation around these objectives, the tasks aimed at bringing them into practice and fulfilling them not only relied on or were the sole responsibility of the Chilean left-wing and the popular movement, "but also of soldiers and professional and democratic officers" 15 . further notes that it is in the ranks of the uniformed where it had taken the "decision to hold the fascist leaders who order and continue ordering the armed forces stained their hands with the blood of men and women in the village"16. Therefore, they conclude that every sector having a democratic and patriotic spirit within the Chilean Armed Forces "has a place in the Antifascist Front," specifying that the same sectors should take "appropriate measures to curb crime and torture first and to judge and then punish those who are accountable for all the crimes committed against the people."

As we may see, the PCCh not only keeps in its analysis (thus, in its military politics) the political assumption regarding the existence and permanence within the Chilean Armed Forces of a segment of professional and democratic military men, which also, when reading the PCCh could and should play a leading role to bring the dictatorship to an end, while preserving the design and the political commitment that granted a central role to this sector of the Armed Forces in the political process of democratic recovery, as well as the safeguard and guarantee of the process of revolutionary structural social changes that would come.

These elements, conceptions, and commitments, in our opinion, involve continuity, almost unrestricted, regarding its military politics, they are a part of the same rationale with

Internacional, que lo publicó en junio y agosto de 1974), In: Desde Chile..., op. cit., 104.

15 Ibid., $103-104$.

${ }^{16}$ Al Partido y al pueblo de Chile. Santiago, 20 de diciembre de 1974, 148. 
the dynamics of politicization should be developed within it. Thus, its leading role determined or shed some significant light on other political aspects that will be defined and developed within the framework of confrontation with the dictatorship, for instance, concerning the struggle forms: "the political development followed by the Armed Forces and Carabinieri is a very decisive factor that will determine both the nature and the form taken by the antifascist resistance" 17 . Similarly, we argue that through the balance made about Allende's defeat, which incorporated more often elements of analysis related to the role of the Armed Forces, as well as from the commitments taken by the PCCh to bring the dictatorship to an end and face the democratic recovery process, there emerged a large number of issues and further discussions regarding military themes, in some cases, they were solved through formal political processes at the level of political leadership, as those developed around the historical gap under the Plenary session of the Central Committee in 1977.

In other cases, the problems opened by the previous discussions in this context were faced in a concrete and fragmented way, even without great definitions or clarifications by the communist leadership, either in terms of prospects or political impact. For instance, the creation in the German Democratic Republic of work teams devoted to investigate the route of the Chilean Armed Forces, the military issue, and the causes of the defeat of Unidad Popular, as well as the decision to educate senior military officers in the Revolutionary Armed Forces of Cuba since 1975 (ÁLVAREZ, 2006; PÉREZ, 2012; PÉREZ, 2013). On the other hand, there emerged a significant amount of new themes and issues from the materialization and development of political initiatives raised by the PCCh leadership based on the fact of facing and filling some issues or gaps in its military politics.

In the case of equipment in the RDA and the professional military men in Cuba, in the short term they not only allowed the emergence of new political issues to be addressed

\footnotetext{
17 Ibid., 148.
} 
and defined, but also ended up bringing in the medium term the processes of political reconfiguration of the PCCh and contributing, inter alia, to the need to rethink some basic precepts of the communist route, which has contributed to the emergence of Política de Rebelión Popular de Masas since 1980 and the expansion and development of the military politics of the PCCh in areas hitherto unknown. For instance, "Trabajo Militar de Masas," which meant incorporating the military in all party structures, and, on the other hand, creating for the first time in the party history, a Fuerza Militar Propia, named as Frente Patriótico Manuel Rodríguez.

\section{Communist balance and self-criticism in relation to the Military Politics in times of Unidad Popular}

Regarding the idea of continuity in the military politics of the PCCh during the Antifascist Front, we may corroborate it by studying the main analyses and balances conducted by the communist leadership and the militancy itself in relation to the nature and design of its military politics during Unidad Popular. The vast majority of these reflections highlights the almost exclusive status shown by the PCCh, working towards the Armed Forces to develop its military politics during Allende's government. In this regard, Luis Corvalán (General Secretary of the PCCh between 1958 and 1990) notes in his memoirs that they concentrated much of the efforts around the Armed Forces, particularly at the high constitutionalist levels. Nevertheless, he explains, the same had been proposed by President Allende, that the PCCh did not regard as relevant to "constitute a party within the military institutions" (CORVALÁN LÉPEZ, 1997, 179).

In relation to these issues and making references to the Plenary session in August 1977, he points out that the most important thing, from the political viewpoint, consists in the conclusive elements of the report concerning the military issue. Accordingly, in the Plenary session people established "as a historical gap of our Party the fact it does not have a clear understanding of the military world and it lacks a military politics." Somehow, he goes further, the belief of a particular Chile, different, among other things, because the "Armed Forces were distinguished by their professionalism and their abstention from the 
political life." However, he recognizes that long before the Coup d'État, they noticed "it was a false conception," and that it had been "the fascist coup that overthrew the government of President Salvador Allende what made us see reality just as it is, demonstrating ad nauseam that fallacy” (CORVALÁN LÉPEZ, 1997, 254-5).

The statement above is of great importance, since it conceptualizes and synthesizes a political assessment on the Chilean experience and the causes of defeat, particularly through one of the topics less frequently addressed by this party, the military issue. Similarly, it may be deduced from the evaluation-conclusion that the centrality of the military politics of the PCCh primarily rested on a construction made by this party concerning the history of Chile and its institutions and more particularly about the view constructed with regard to the Chilean Armed Forces (FURCI, 2008). Based on these conceptions, the military politics emerged and set on it the centrality of working towards the Armed Forces as the key point.

Meanwhile and following the same line of analysis, Guillermo Teillier ${ }^{18}$ indicates that in the 1977 Plenary session it was also concluded that people were not able to safeguard the conquests and transformations developed during Unidad Popular, something which turned the military aspects of the politics into one of the greatest weaknesses in the route of the party. He also notices that it is not correct to conclude that a conception of military work does not exist, that it would be based on "the work of relations with the institutional Armed Forces." He highlights that before Allende's triumph and during his government they believed to have a significant number of senior officers, non-commissioned officers, and troops loyal to the government having constitutionalist ideas, and this implied that "in a way or another they had to observe the popular will." It is estimated regarding the military politics of the PCCh and concerning the defeat of Unidad Popular that the main aspect was failing to prepare "the people on a political basis to defend the Government. That was the most important thing"19. On the contrary, he adds that the politics of not

\footnotetext{
${ }^{18}$ Gullermo Teillier, General Secretary of the PCCh between 2002 and 2005, and since 2005 its President; member of the Interior Direction Team in the clandestine period and head of the Military Commission during the deployment of the popular rebellion politics, between 1982 and 1987 (HERREROS, 2003, 206).

19 Interview cited by HERREROS (2003, 206-207).
} 
producing situations that justify responses from reactionary sectors and usurpers prevailed.

More, he believes people did not take into account "that was a kind of fatality, that something equal was coming, because there were too many signs (...) we could not fool ourselves, and we got the slogan No Civil War." In face of this, he specifies that people did not want a civil war, but "perhaps the slogan from the beginning might be We Should Defend the Popular Government and Workers' Achievements. We were in need to call and prepare since the beginning for this." Finally, he self-critically notices that having the importance assigned by the party to working with the Armed Forces as a basis, which was estimated to be supported by important constitutionalist segments, not only to uphold the constitution, but also popular will, corresponded to deepen and work much more with these segments, and they also should "have tried to change the nature of the Armed Forces, from the doctrinaire viewpoint, as well as that of control boards, etc."20.

In relation to the same issues, Francisco Herreros said that "the military conception of the PCCh was based on trust, professionalism, and constitutional subordination of the Chilean Armed Forces" and it aimed at "constructing a correlation of political and social forces sufficiently strong and firm that dissuaded them to depart from that cause" (HERREROS, 2003, 185). On the other hand, when analyzing the military politics of the PCCh, as well as the political route of this Party up to Unidad Popular, Luis Rojas said that during "almost its entire existence, within the party there was a prevailing belief that the Armed Forces are subordinate to civil authority and obey the Constitution of the Republic" (ROJAS, 2011, 170).

Other elements of analysis and characterization of the military politics of the PCCh during Unidad Popular are revealed by the testimony of Carlos Toro, Deputy Director of Research (civil police) during Allende's government and member of the Military Commission of the PCCh in the context of the Coup d'État. According to him, the PCCh did have a military politics during this period and by means of its Military Commission it developed operational plans based on the defense of the Government, which were

\footnotetext{
${ }^{20}$ lbid. 207-208.
} 
designed by considering the participation of major political and social forces. According to Toro, the "plan started from the assumption that the main strongholds for the defense of the Popular Government were workers and organized peasants, the student and young masses, in other words the people" (TORO, 2007, 56). However, the central part of the plan fell materially and militarily on the constitutionalist segment of the Armed Forces, Carabinieri, and Investigations. According to Toro, from the political viewpoint, the key "was the defense of the Government, the Constitution, the rule of law, and democracy. The need to crush any usurping attempt." To do this, people thought of the plan or "started from the assumption that usurpers would not rely on the direction of the Army, they would not lean on the Commander in Chief of the Army, General Carlos Prats" (TORO, $2007,30)$.

It is also stated that militarily the Government defense plan was built taking into account certain basic political premises for the PCCh. One of them, perhaps the main one, is related to the disposition of forces within the Army: it was thought, Toro points out, that the usurpers did not have all the military forces in this branch of the Armed Forces, and both General Carlos Prats, Commander in Chief, and most of the corps of generals followed the so-called Schneider Doctrine, "which involved political abstention from those in uniform, compliance and defense of the Constitutional Government, subjection to the guidelines of the President of the Republic and the right of the latter to fulfill the program offered to the people" ( TORO, 2007, 57).

The weaknesses or gaps in the military politics of the PCCh in times of Unidad Popular are precisely what started to be solved during the early years of the dictatorship. Hence the importance of reviewing and considering the communist self-criticism, as it allows us to perceive the dynamics of continuity and change that marked this period of party history, as well as the elements that stressed the military politics of the PCCh during the Antifascist Front. 
The struggle forms and the military politics of the PCCh under the Antifascist Front

Another way of identifying the most important and general features of the military politics of the PCCh is by analyzing the tactical commitments it raises and the political conceptions behind them. The latter, for instance, set the contours and fundamental dynamics through which the struggle forms taken by the PCCh against the dictatorship should move and develop. Similarly, the political references towards the Armed Forces, the struggle forms established and developed by the PCCh provide us with significant elements to identify and characterize the military politics, the viewpoints on the Armed Forces, and the politics of this party towards them.

In relation to the struggle forms, we noticed that a significant element of the communist political tradition is the centrality assigned to mass struggle in the revolutionary process. In this regard, we could propose a kind of consensus among researchers who study the Chilean left-wing and particularly the Chilean communism in relation to this statement, and some authors point out that the PCCh did so in the worst repressive passages of party history, such as in times of greatest growth and political radicalization within the framework of the fight against the dictatorship, especially in the period 19831988 (MOULIAN Y TORRES 2010; VENEGAS, 2009; ÁLVAREZ, 2011; BRAVO 2010). Thus, during the Antifascist Front politics, mass struggle did not lose its importance and it became a key point of all the recurring political repertoire in the statements and documents. As a final word or last slogan, there was always the centrality of mass struggle in most of the party documents. It is also interesting that, as a counterpart, there emerged an important criticism and recurrent rejection to armed struggle forms provided by MIR against the dictatorship, especially in the period 1973-1977.

For instance, in a public statement on December 15, 1973, the PCCh claimed that "terrorism and provocation are alien to the front line of the people in order to bring the dictatorship to an end." Regardless of the origin of provocations, they are always a tool in favor of oppressors. According to the PCCh, the restoration of democracy would be achieved by avoiding the route of putsch and adventurism, concluding that "Mass struggle is the only way to win!" Thus, the PCCh clearly sets the main dynamics that might shape the 
struggle forms to be developed by the militancy. The latter should be determined by considering the need to gather all democratic forces opposed to fascism. They should address in each situation, "the level of consciousness reached by the masses" as well as the "actual correlation of forces and the need that each action improves this correlation of forces in favor of the people"21.

Once these criteria are clear, people established that the route "of individual terror or putsch" should be avoided. According to the PCCh, the Board hoped that "the people seek this kind of action," as it allowed them to justify the repressive politics. They concluded by having the historical experience and the scenario that opened up with the installation of the Military Board as a basis that long ago "ultraism and provocation provided a considerable support to the enemies of the people. Similarly now, adventurist action is what the fascist Leigh wants to impose his game"22. In this context, the commitment of the PCCh was focused on pursuing a broad mass movement against the Military Board in order to deepen its isolation, since no revolutionary process will succeed unless it has a broad mass force. Finally, people reaffirm again the military politics pursued during Unidad Popular, by proposing to withdraw from conflict having the construction of a large majority in opposition to the dictatorship as a basis (in the times of Unidad Popular it was against the usurping sectors), allowing a favorable correlation of forces capable of stopping or "tie the hands" of those sectors that would unleash violence against most of the country.

In this regard, we estimate there is a major political continuity between the guidelines issued to deal with the Military Board and those raised by the PCCh in the last period of Unidad Popular, especially in the conceptions and commitments launched to face the onslaught of the reactionary sectors and usurpers that were synthesized in the slogan No Civil War. The key and decisive point for the PCCh, not only in relation to the objectives linked to the construction and materiality of the Antifascist Front, but also regarding the

\footnotetext{
${ }^{21}$ El Partido Comunista denuncia provocación. Santiago, 15 de diciembre de 1973, In: Desde Chile..., op. cit., 37 y 46.

${ }^{22}$ Ibid. Más adelante, en “Los Acontecimientos de Chile: Visión de los Comunistas”, de junio de 1974, plantean la misma idea pero cambiando el concepto ultrismo por terrorismo: "En el pasado, el terrorismo y la provocación prestaron considerable ayuda a los enemigos del pueblo. Ahora, dado el tipo de opresión, el resultado sería peor." (Desde Chile..., op. cit., 105).
} 
defeat of the dictatorship, "is mass work." According to the PCCh, there is "no tactics capable to replace this work as the key issue of victory. There is no way out, no matter what is its shape, it is not possible to succeed without mass action. Their participation determines victory." Then, they proposed to avoid the emergence within the popular movement of ideas and attitudes involving passive expectation of a solution alien to the mass movement, and pointed out that the Military Board would massify the idea concerning the emergence of alleged parallel governments in exile and "that armed groups might be prepared abroad to overthrow them," tainting the international solidarity movement against the dictatorship, depicting it as something alien and interventionist, and dragging "the popular masses to inactivity, passive tolerance of exploitation and abuse, waiting for the 'big day' or 'great action' to determine change"23.

Undoubtedly, one of the most important party productions concerning the struggle forms, as well as the military politics sought by the PCCh during the Antifascist Front is the document entitled "El ultraizquierdismo, caballo de Troya del imperialismo." By means of this document, the PCCh carries out a political discussion with MIR, on the one hand, regarding the open issues of the Chilean left-wing that depend on the characterization of the dictatorship, on the other hand, in relation to the political tactics to develop in order to bring it to an end. A special mention is obtained in this regard by the discussions proposed concerning the alliance-based politics, the work towards the Armed Forces and struggle forms to be developed by the Chilean left-wing and the popular movement against the dictatorship, namely the issue of armed struggle.

Regarding the military theme, people establish that, as a party of the working class, they take the need to face the military issue, seeing it as "the correlation of forces at the military level, which is immediately decisive correlation in the definition of fight for power." And the key point concerning this issue is "the creation of such a correlation of military forces favorable to the revolutionary process, capable of preventing and suffocating attempts of reaction to perpetrate their privileges by resorting to weapons." In the same vein, they explain that there may not be a favorable correlation of forces at a military level

\footnotetext{
${ }^{23}$ Al Partido y al pueblo de Chile. Santiago, 20 de diciembre de 1974, In: Desde Chile..., op. cit., 149.
} 
capable of ensuring the victory of the revolutionary process, "if a favorable correlation of political forces is not built," i.e. "if people cannot gather around revolutionary forces major social forces against those that manage to group the enemies of the people," in order to conclude that it was just "the consolidation of such precondition, needed, what we did not get in the period of the Popular Government and this primarily determined our defeat"24.

Regarding the military politics of the PCCh during Unidad Popular, people point out it was mainly aimed at reinforcing "the constitutionalist positions within the Armed Forces," political views or conceptions "that meant respect for the Popular Government and faced the fascist efforts to turn the Armed Forces into restorers of the power of oligarchy and imperialism." It was expected, through these positions, that the Armed Forces might join the economic and social development process carried out by Unidad Popular, as this benefited most of the nation. During this process, the PCCh highlights, "a growing identification of members of the Armed Forces with the country's need for progress, and then the revolutionary process." And, according to the PCCh, the failure of this politics was mainly due to change in the correlation of political forces at the expense of the movement and the Popular Government, the fact that the political guidelines in relation to the Armed Forces were not organically materialized by all political forces that formed Unidad Popular and the overestimation of the capabilities of Constitutionalist sectors in the military corps, as well as "the weight of democratic feelings within the armed agencies"25.

Regarding the work towards the Armed Forces, we may first identify a clear link between their political commitment to the military agencies and their general politics, the Antifascist Front. According to the PCCh, the definition and insertion of work towards the Armed Forces should take place in the context of the main political contradiction established by this party for this period, i.e. between fascism and democracy. Based on this, the task set by the PCCh in this context was "bringing on these institutions the feelings and ideas of most of the country." In relation to this line of work, they explain, there was

\footnotetext{
${ }^{24}$ El Ultraizquierdismo, Caballo de Troya del Imperialismo. Santiago, Septiembre de 1975. In, Desde Chile, op. cit., 225-226.

25 Ibid. 226.
} 
a need to consider "preferably soldiers, classes, and non-commissioned officers," since because of their class status, they were more directly linked to the issues of most people, allowing them to see in an easier way and more quickly the urgency to bring the dictatorship to an end. However, they indicate that "at different degrees, this also weighs on officialdom, mostly linked to middle classes vastly dispossessed by fascism"26.

Based on the conceptions and arguments above, they propose that the Antifascist Front should have among its objectives the need to build Armed Forces loyal to the people, which really observe "the political power that the people freely decides to provide." In these military institutions, they explain, there will be no room for fascist sectors, linked to torture and corruption. Regarding the involvement of military men in the process and dynamics of struggle against the dictatorship, people point out as a decisive aspect the emergence of antifascist feeling among most members of the Armed Forces, the rise and development of mass struggle, particularly driven by the working class and the people: through the mobilization of "big masses antifascist feelings will strongly open their path within the Armed Forces and unity between the people and members of the Armed Forces will crystallize in the very course of these class struggles"27.

In relation to the struggle forms, they propose a significant political relationship between the centrality of mass struggle and military politics, establishing a harsh criticism to the "adventurist" and "terrorist" action of MIR: "ultra-leftism remains attached to terrorism as a decisive element of its political project as a whole," criticizing armed actions against the dictatorship, such as armed propaganda, harassment of the repressive apparatuses, or punishment of torturers, murderers, or agents of the dictatorship. Regarding these struggle forms, they are defined as having the nature of or being a part in "a terrorist plan, even when not only innocent individuals die in the actions," because "each of such 'tasks' may not be but actions taken by individuals or small groups detached from the masses and never by the masses themselves under the current conditions." According to the PCCh, only "through mass struggle a revolutionary situation will be created, and thus the basic conditions for a political correlation and a favorable military

\footnotetext{
${ }^{26}$ lbid. 227-228.

27 Ibid. 228.
} 
correlation to the popular forces." Therefore, proposing the construction of a "proletarian and popular military power," as postulated by MIR, through terrorist actions, is a delusion, not only because it means building a military force stronger than that of the Chilean Armed Forces, but mainly because they are conceived "outside the actual class struggle"28.

Given the above, we estimate that the PCCh recognized the weaknesses and inadequacies of its military politics during the Government of Unidad Popular (for purposes of analysis regarding Allende's defeat), and continuity was also given to it during the Antifascist Front politics. These aspects may be identified in many party documents and statements prepared both by the communist leadership located in Chile and in exile. An example of the latter consists in Américo Zorrilla's proposition, member of the Political Committee of the PCCh, which claimed to be mandatory "preparing the working class and the masses to fight against the counter-revolution in all fields, including the military one. The task of defending the revolution requires mastering and being able to apply all struggle forms"29.

In this regard, we believe that during the period 1973-1977 the PCCh had already faced on a political basis some key aspects and issues of its military politics that were subsequently listed in the 1977 Plenary session as a "historical gap." Thus, the "gap" had already been growing since the limitations of the politics were recognized, and the first teams to address these issues were formed in 1974 and the process of educating professional military men in Cuba began in April 1975. These commitments are strongly consistent with the general politics of the PCCh and they are directly related to the balances made by the communist leadership concerning the Chilean experience, the needs to solve in order to face the dictatorship and to meet the challenges in a hypothetical scenario of democratic recovery. What is important in our view was the background or route of these initiatives, their particular political unfolding within the general framework of struggle against the dictatorship, internal party discussions, and the concrete experience concerning the specificity of the tasks. In this sense, it might be argued that the political initiatives carried out by the PCCh to solve a large part of its weaknesses in terms

\footnotetext{
28 Ibid. 231-232.

${ }^{29}$ Acerca de Lenin y la defensa de la revolución, In: Don Américo, op. cit. (1993, 141).
} 
of the military politics also produced a significant amount of new gaps. In short, the gaps to be bridged in relation to the military politics, after the 1977 Plenary session, were not designed in terms of how to defend the conquests of the working class and the people in a hypothetical new popular government, but in view of the defeat of the dictatorship.

The latter aspect-goal will become one of the key elements of the military politics of the PCCh since the late 1970s, as reflected in the 1979 Plenary session of the Central Committee of the PCCh, where a concern to develop its own Military Force emerged for the first time, everything in face of the imminent extension and institutionalization of the dictatorship ${ }^{30}$. It is in this historical context and through the emergence of Política de Rebelión Popular de Masas, in September 1980, which sponsored all struggle forms to bring the Pinochet era to an end, including violence, where emerged and gained momentum - along with the traditional work towards the Armed Forces - the Military Mass Work and the Military Force itself (Frente Patriótico Manuel Rodríguez), the new components of the military politics of the PCCh during the 1980 s.

${ }^{30}$ Informe al Pleno del Comité Central del Partido Comunista de Chile (1979). 


\section{Referencias}

\section{Documentations}

Boletín del Exterior. Partido Comunista de Chile.

CORVALÁN LÉPEZ, Luis. La revolución chilena, la dictadura fascista y la lucha por derribarla y crear una nueva democracia. Informe al Pleno del Comité Central de agosto de 1977. Santiago: Ediciones Colo-Colo, 1978.

Desde Chile hablan los comunistas! Santiago: Ediciones Colo-Colo, 1976.

Don Américo. Un chileno Comunista. Homenaje póstumo. Santiago: s/e, 1992.

Informe al Pleno del Comité Central del Partido Comunista de Chile. 1979. En: Hacia el XV Congreso del Partido Comunista de Chile. Documentos para el enriquecimiento del debate. Santiago, 1989.

\section{Books, serials, and theses}

ÁLVAREZ, Rolando. Desde las sombras. Una historia de la clandestinidad comunista (19731980). Santiago: LOM, 2003.

ÁLVAREZ, Rolando. ¿La noche del exilio? Los orígenes de la rebelión popular en el Partido Comunista de Chile, In: VALDIVIA, Verónica; ÁLVAREZ, Rolando y PINTO, Julio. Su revolución contra nuestra revolución. Izquierdas y derechas en el Chile de Pinochet (19731981). Santiago: LOM, 2006, 101-152.

ÁLVAREZ, Rolando. Arriba los pobres el mundo. Cultura e identidad política del Partido Comunista de Chile entre democracia y dictadura. 1965-1990. Santiago: LOM, 2011.

BASCUÑÁN, Carlos. La izquierda sin Allende. Santiago: Editorial Planeta, 1990.

BRAVO, Viviana. ¡Con la razón y la fuerza, venceremos! La rebelión popular y la subjetividad comunista en los '80. Santiago: Ariadna Ediciones, 2010.

CAMPERO, Guillermo. Los gremios empresariales en el periodo 1970-1983: Comportamiento sociopolítico y orientaciones ideológicas. Santiago: ILET, 1984.

CORVALÁN LEPE, Luis. De lo vivido y lo peleado. Memorias. Santiago: LOM Ediciones, 1997. 
CORVALÁN MARQUEZ, Luis. Del anticapitalismo al neoliberalismo: Izquierda, centro y derecha en la lucha entre los proyectos globales. 1950-2000. Santiago: Sudamericana, 2002.

FURCI, Carmelo. El Partido Comunista de Chile y la vía al socialismo. Santiago: Ariadna Ediciones, 2008.

GÁRATE, Manuel. La revolución capitalista de Chile (1973-2003). Santiago: Editorial Alberto Hurtado, 2012.

GOICOVIC, Igor. La refundación del capitalismo y la transición democrática en Chile (19732004), In: Historia Actual Online, no. 10, Asociación de Historia Actual/Universidad de Cádiz, Cádiz, 2006, 7-16.

HERREROS, Francisco. Del Gobierno de pueblo a la Rebelión Popular. Historia del Partido Comunista 1970-1990. Santiago: Editorial Siglo XXI, 2003.

MOULIAN, Tomás. Chile actual. Anatomía de un mito. Santiago: LOM, 1997.

MOULIAN, Tomás y TORRES, Isabel. Continuidad o cambio en la línea política del Partido Comunista de Chile. En: VARAS, Augusto; RIQUELME, Alfredo y CASALS, Marcelo (editores). El Partido Comunista en Chile. Una historia presente. Santiago: Editorial Catalonia - USACH - FLACSO, 2010, 291-326.

PÉREZ, Claudio. De la guerra contra Somoza a la guerra contra Pinochet. La experiencia internacionalista y la construcción de la Fuerza Militar propia del Partido Comunista de Chile, In: PÉREZ, Claudio y POZZI, Pablo (edits). Historia oral e historia política: Izquierda y lucha armada en América Latina, 1960-1990. Santiago. LOM Ediciones, 2012, 213-244.

PÉREZ, Claudio. Gonzalo: Militancia e internacionalismo. Una aproximación histórica al desarrollo de la Tarea Militar del Partido Comunista de Chile, In: PENSADO, Patricia (coord.). Experimentar en la Izquierda: Historias de militancias en América Latina, 19501990. CLACSO. Buenos Aires, 2013, 102-128.

PINTO, Julio. ¿Y la historia les dio la razón? El MIR en Dictadura, 1973-1981, In: VALDIVIA, Verónica; ÁLVAREZ, Rolando y PINTO, Julio. Su revolución contra nuestra revolución. Izquierdas y derechas en el Chile de Pinochet (1973-1981). Santiago: LOM, 2006, 153-205.

RIQUELME, Alfredo. Un rojo atardecer. El comunismo chileno entre dictadura y democracia. Santiago: Centro de Investigaciones Diego Barros Arana, 2009. 
ROJAS, Luis. De la rebelión popular a la sublevación imaginada. Antecedentes de la Historia Política y Militar del Partido Comunista de Chile y del FPMR, 1973-1990. Santiago: LOM, 2011.

TIRONI, Eugenio. Los silencios de la revolución. Chile: la otra cara de la modernización. Santiago: Editorial Antártica, 1988.

TORO, Carlos. La Guardia muere, pero no se rinde... mierda. Memorias de Carlos Toro. Santiago: (sin editorial), 2007.

VALDIVIA, Verónica. El golpe después del golpe. Leigh v/s Pinochet, 1960-1980. Santiago: LOM, 2003.

VARAS, Augusto. De la violencia aguda al registro electoral: estrategia y política de alianzas del PC, 1980-1987. En VARAS, Augusto; RIQUELME, Alfredo y CASALS, Marcelo (editores). El Partido Comunista en Chile. Una historia presente. Santiago: Editorial Catalonia - USACH - FLACSO, 2010, 335-347.

VENEGAS, Hernán. El Partido Comunista de Chile: desde su tradición aliancista al aislamiento político como resultado de su estrategia de Rebelión Popular de Masas. 19221989. Huelva: Universidad de Huelva, 2008 (Tesis de doctorado en Historia).

VENEGAS; Hernán. Trayectoria del Partido Comunista de Chile. De la crisis de la Unidad Popular a la política de rebelión popular de masas, In: Universum, vol 2, no. 24, Instituto de Estudios Humanísticos Juan Ignacio Molina de la Universidad de Talca. Talca, II semestre de 2009, 262-293. 